\title{
Environmental and ecological architects: Guidelines for the Chilean temperate rainforest management derived from the monito del monte (Dromiciops gliroides) conservation
}

\author{
Arquitectos ambientales y ecológicos: Pautas para la gestión ambiental del bosque \\ templado lluvioso de Chile derivadas de la conservación del monito del monte \\ (Dromiciops gliroides)
}

\author{
FRANCISCO E. FONTÚRBEL ${ }^{1, *}$ \& JAIME E. JIMÉNEZ ${ }^{2,3}$ \\ ${ }^{1}$ Departamento de Ciencias Ecológicas, Facultad de Ciencias, Universidad de Chile, Casilla 653, Santiago, Chile \\ ${ }^{2}$ Laboratorio de Vida Silvestre, Universidad de Los Lagos, Osorno, Chile \\ ${ }^{3}$ Present address: Department of Biology and Department of Philosophy and Religion Studies, University of North Texas, \\ Denton, TX 76203-5017, USA \\ ${ }^{*}$ Corresponding author: fonturbel@gmail.com
}

\begin{abstract}
Land use change is one of the main biodiversity threats. Due to this change, natural habitats such as the South American temperate rainforests have been rapidly degraded, fragmented, and lost. Consequently, the management and conservation of the remaining forest is a priority and having an appropriate environmental policy is mandatory for this purpose. Conservation actions in the temperate rainforest have been addressed from an individual species perspective, giving less attention to the ecosystem level conservation. Moreover, conservation-related information has not reflected yet on environmental policy development. We used the case study of the monito del monte (Dromiciops gliroides) to illustrate how our current ecological and conservation knowledge of a species could be used to generate a new environmental policy. Dromiciops gliroides is a forest-dependent species with an important ecological role and quite unique evolutionary status. In order to guarantee the persistence of $D$. gliroides, we propose two habitat management components to be incorporated in management plans: structure and connectivity. Structure refers to spatial arrangement and key structural elements that determine habitat quality and connectivity refers to functional connectivity at the landscape level. The conservation of the monito del monte might also contribute to the conservation of many other forest-dependent species. By conserving such species it will be possible to conserve the ecological interactions and the eco-evolutionary processes, which ultimately determine the conservation of the temperate rainforest.
\end{abstract}

Key words: environmental policy, management plan, natural regeneration, plant-animal mutualism, rainforest.

\section{RESUMEN}

El cambio de uso de la tierra es una de las principales amenazas a la biodiversidad. Hábitats naturales como el bosque templado lluvioso de Sudamérica han sido degradados, fragmentados y eliminados rápidamente. En consecuencia, es prioritario el manejo y conservación de los remanentes, para lo que es necesario contar con una política ambiental acorde. Las acciones de conservación referentes al bosque lluvioso templado se han abordado mayormente desde una perspectiva de especies individuales, con poco énfasis en la conservación a nivel de ecosistema. Más aún, la información generada en este ámbito tampoco ha permeado en el desarrollo de políticas ambientales. Utilizamos el estudio de caso del monito del monte (Dromiciops gliroides) para ilustrar cómo el conocimiento actual en ecología y conservación de una especie puede ser utilizado para generar una nueva política ambiental. Dromiciops gliroides es una especie dependiente del bosque, con un importante rol ecológico y un gran interés evolutivo y de conservación. Para garantizar su persistencia, proponemos dos componentes de gestión del hábitat, a incorporarse en los planes de manejo: la estructura y la conectividad. La estructura hace referencia al arreglo espacial y la presencia de elementos estructurales clave que influyen en la calidad del hábitat, mientras que conectividad se refiere a la conectividad funcional del paisaje. Conservando al monito del monte, se conservarían también otras especies dependientes del bosque y así las interacciones ecológicas y los procesos ecoevolutivos, que determinan finalmente la conservación del bosque lluvioso templado.

Palabras clave: bosque lluvioso, mutualismo planta-animal, plan de manejo, política ambiental, regeneración natural. 


\section{INTRODUCTION}

Human activities have modified natural habitats since prehistoric times, with a remarkable intensification after the arrival of the industrial era (Armesto et al. 2010). As a result, there is currently a biodiversity loss crisis. Even though this situation has been acknowledged in the last decades, the environmental policies and conservation actions have only been developed quite recently (Butchart et al. 2010). Land use change is one of the most worrisome threats to biodiversity worldwide (Sala et al. 2000) and it is closely related to habitat loss, fragmentation, and transformation (Chapin III et al. 2000). All these factors might compromise the long-term persistence of many species, given that their life history traits determine their sensitivity to habitat modifications (Vásquez \& Simonetti 1999, Vergara \& Armesto 2009).

Special attention has been given to hot-spot sites around the world (Myers et al. 2000, Mittermeier et al. 2005) in order to preserve ecosystems with high biodiversity and endemism levels, currently threatened by human actions. Among them, high endemism in temperate ecosystems, such as the South American temperate rainforest (SATR) has been less studied than tropical ecosystems. This particular forest is facing rapid fragmentation and loss (Echeverria et al. 2006, 2007), because of the expansion of urban centers and farming activities (Armesto et al. 2010). The remaining SATR stands are highly fragmented, immersed in a complex mosaic of anthropogenic matrices. Such matrices range from plain grasslands to commercial forest plantations, increasing edge effects (Bentley 2008) and reducing habitat quality.

Conservation issues at the SATR have been mostly handled species-by-species, focused on species with critical conservation status. However, the conservation of functionality of these forests has not been taken into consideration. Few studies have addressed the impact of human disturbances on ecological interactions (e.g., Valdivia et al. 2006, Simonetti et al. 2007, Valdivia \& Simonetti 2007, Martinez-Harms \& Gajardo 2008). Moreover, habitat degradation, loss, and fragmentation could disrupt key mutualisms (e.g., Rodríguez-Cabal et al. 2007) and negatively affect natural regeneration. As the
SATR has a highly endemic biota, plant-animal mutualisms (such as pollination and seed dispersal) are remarkably important in maintaining biodiversity (Aizen et al. 2002). Therefore, an ecosystem conservation approach would be preferred, rather than single species-based conservation actions.

For a successful habitat conservation approach, appropriate environmental policies are necessary, aiming to create a national framework for management and conservation. However, environmental policy and biodiversity conservation studies are commonly treated separately (e.g., Margalida et al. 2010), each focusing on resolving their particular problems without an explicit connection. Environmental management and conservation sciences share many ecological elements, even if they usually operate at different spatial scales. In this short essay, we aim to use the case study of an endemic South American ancient marsupial, to show an example of an explicit connection between research conducted on the ecology and conservation of a particular species. We propose the development of environmental policies intended to successfully manage the SATR, considering its functional and structural aspects.

\section{DROMICIOPS GLIROIDES AS A MODEL SPECIES}

The monito del monte (Dromiciops gliroides Thomas) is considered a conservation priority for being the only extant species of the Microbiotheria Order (Marshall 1978), and because of its ecological role as seed disperser of many native species (Amico et al. 2009). Thus, $D$. gliroides can help significantly to the natural regeneration of the native vegetation (García et al. 2009, Carmona et al. 2010). This species has not been studied in detail until the last decade. Recent research has shown that $D$. gliroides is not as scarce as it was assumed to be, when specific sampling methods were developed (Fontúrbel \& Jimenez 2009, Fontúrbel 2010). We also have a much better understanding of this species' tolerance to habitat degradation, emphasizing its role as a regeneration agent. In spite of such tolerance, studies regarding spatial ecology have shown that $D$. gliroides can disperse through riparian corridors (Smith- 
Ramírez et al. 2010), but cannot move across open habitats, such as prairies (Fontúrbel et al. 2010). Such behavior precludes its dispersal among forest remnants immersed into non-forested matrices, experimenting a "fence effect" (Lindenmayer et al. 1999).

Dromiciops gliroides is an endemic marsupial of the Chilean and Argentinean SATR distributed from Los Queules National Reserve $\left(35^{\circ} \mathrm{S}\right)$ to Chiloé island $\left(44^{\circ} \mathrm{S}\right)$, comprising both Coastal and Andes ranges and the intervening lowlands (Kelt \& Martínez 1989, Lobos et al. 2006). This species is morphologically and physiologically adapted to cold and moist forests (Hershkovitz 1999, Bozinovic et al. 2004). It was thought to be restricted to oldgrowth native stands dominated by Nothofagus spp. and Araucaria araucana (Hershkovitz 1999). However, recent research has shown that $D$. gliroides is also found in small $(<5 \mathrm{ha})$ Myrtaceae-dominated second-growth forest fragments (Fontúrbel et al. 2010), in which it has shown similar population densities than those found in old-growth fragments (see also Celis-Diez 2010, Smith-Ramírez et al. 2010), as long as these fragments retain key structural elements such as fallen logs, stumps, leaf litter, snags, shrubs, and a dense bamboo cover. In Argentina, nevertheless, forest fragmentation has shown a negative effect on $D$. gliroides' densities (Rodríguez-Cabal et al. 2007).

Small-bodied species like this marsupial are usually associated to structurally complex habitats. In that sense, structural complexity determines habitat texture, which also influences mobility and shelter-provisioning (Bro-Jørgensen 2008, Fischer et al. 2008). However, human disturbance can significantly alter habitat complexity for $D$. gliroides. Anthropic pressures can change canopy height and cover, branch diameter and density, leaf litter abundance, vine abundance, moss abundance, shrub cover, bamboo cover, as well as the presence of fallen logs, stumps, and snags (Jaña-Prado et al. 2006). Such changes can dramatically reduce cavity availability (i.e., nesting sites) by removing coarse woody debris (usually used as firewood), as has been shown for forest cavity nesting birds (Cornelius et al. 2008, Cockle et al. 2010) and marsupials (Lindenmayer et al. 1999, Gibbons et al. 2002). Despite this, there is no formal study on cavity limitation for $D$. gliroides. The use of nest boxes and its increasing occupancy trend over time (Franco 2009) suggest that natural cavities might in fact be a limiting resource for this species in second-growth stands. Nesting boxes occupancy increased from $20 \%$ to $40 \%$ in three years (LM Franco, personal communication, 2010).

The reduction of branch, shrub, and bamboo density might diminish shelter sites and intrafragment dispersal paths. Such habitat structure seems essential in order to attain long-term persistence (Vergara \& Schlatter 2008). Those aspects are well documented for forestdependent birds. Forest bird richness, abundance, and guild composition has shown significant changes as a function of habitat structure (Diaz et al. 2005). Specifically, structural simplification would cause a decline on forest bird diversity. Moreover, structural components such as understory density might determine movement possibilities for dispersallimited species, such as rhynocriptids (e.g., Scelorchilus rubecula, Pteroptochos tarnii) (Castellón \& Sieving 2006a, 2007).

In summary, habitat degradation could negatively affect $D$. gliroides in two main aspects: shelter and food provisioning. Shelter would be a limiting resource when cavities on live trees and fallen $\log s$ are reduced by human action. Also nesting materials (mosses and bamboo leaves; Jiménez \& Rageot 1979) could be a limiting resource on degraded forests (Diaz et al. 2006). On the other hand, the reduction of vines and understory vegetation would reduce food (i.e., fleshy fruits and insects) availability, as well as potential dispersal paths needed to search for food (Jaña-Prado et al. 2006, LM Franco, personal communication, 2010) and compromise mobility (Gallardo-Santis et al. 2005). Consequently, habitat structure could limit habitat use possibilities (Vergara \& Schlatter 2008, Vergara \& Armesto 2009), as reported for other forest-dependent species (e.g., Sieving et al. 2000, Reid et al. 2004).

\section{STRUCTURE AND CONNECTIVITY: LINKING CONSERVATION RESULTS WITH ENVIRONMENTAL POLICY}

A sound environmental policy should be based on hard ecological knowledge (Lindenmayer 
1999). Ecological and conservation knowledge should be used to design forest conservation and management plans at the scale of the biome. Maintaining ecosystem functionality and its evolutionary trajectory depends on preserving the ecological interactions. Previous works highlighted understory birds as umbrella species for SATR conservation (e.g., Castellón \& Sieving 2007). Here, we go further by proposing the use of an endemic mammal, with an exceptional ecological role. Our current ecological knowledge on $D$. gliroides points to its outstanding role maintaining pollination and dispersal services (Aizen 2003), on which the ecosystem persistence and identity relies, and supports it as a model species for conservation and management (Lindenmayer et al. 2002). Being the sole disperser of the native mistletoe Tristerix corymbosus (Amico \& Aizen 2000, Amico et al. 2011), this marsupial guarantees the food supply for many other species, especially for the hummingbird Sephanoides sephaniodes, which depends on this mistletoe for feeding in winter (Aizen 2003). Conserving mutualists has an exceptional ecosystem conservation value, considering that about 75 $\%$ of the SATR plants depend on such mutualisms (Aizen \& Ezcurra 1998).

In order to maintain D. gliroides' ecological dynamics that may serve as a model species to maintain SATR ecological processes, we propose two key components that should be considered on the environmental policy: habitat structure and connectivity.

\section{Habitat structure}

Habitat structure component has two main axes: geometry and fine-grain structure. The former operates at the landscape scale and is determined by the spatial arrangement of patches, while the latter does it at the patch scale. Thus, landscape attributes such as fragment size, shape, and its spatial distribution (randomly, uniformly, or aggregated in patches) determine dispersal possibilities as well as the amount of suitable habitat available for a particular species (Fahrig 1997, 2003, Lindenmayer \& Fischer 2006). Additionally, those landscape attributes also determine the extent of edge effects (Ries $\&$ Sisk 2004). Small and irregular fragments will experiment larger edge effects than large and rounded patches. Regular fragments have larger core areas than irregular ones and hence, larger potential carrying capacities for the species therein (Castellón \& Sieving 2007).

Additionally, metapopulation dynamics could be achieved if patches are large and close enough to maintain local populations, and would allow inter-patch dispersal (Wiens 1997). Despite the fact that $D$. gliroides metapopulation dynamics has not been assessed yet, telemetry (Franco 2009, Fontúrbel et al. 2010) and corridor-use evidence (Smith-Ramírez et al. 2010) suggest that it would be similar to Castellón \& Sieving's (2007) model for $S$. rubecula. In that sense, spatially-explicit scenarios should be used in order to estimate the proportion of SATR remnants that would constitute suitable habitat for forest-dependent species. If this consideration is taken into account when managing forest remnants, the amount of suitable habitat for $D$. gliroides and other forest species could be maximized.

On the other hand, fine-grain structure axis refers to the presence and quantity of key structural elements in each forest patch. Structural elements such as canopy height and cover, cavities, branches, vines, mosses, and others determine that microhabitat conditions could be seen as niche axes (Vásquez 2005). The presence and abundance of those structural elements determine the habitat quality of each forest remnant (Beyer et al. 2008, Vergara \& Armesto 2009) and could be lost due to human action: directly, through its removal for firewood or other uses, and indirectly, by livestock grazing. Recent work (Rodríguez-Cabal 2008, García et al. 2009) has shown that, in Argentina, the presence of $D$. gliroides is related to $T$. corymbosus abundance at a smaller scale. However, this pattern was not detected in Chile (Smith-Ramírez et al. 2010). At a broader scale, D. gliroides presence is associated with bamboo cover (see also Patterson et al. 1990). Bamboo cover is also a major factor for understory birds (e.g., Sylviorthorhynchus desmursii), influencing abundance of invertebrates as food resource (Reid et al. 2004). An abundant understory may also have a positive effect on $D$. gliroides, by providing invertebrates that constitute an 
important item of its diet (Jiménez \& Rageot 1979, Quijano 2008).

\section{Connectivity}

Two axes determine the connectivity component: landscape composition and the nature of the surrounding matrix. Forest composition relies on how forest patches of different size classes are distributed along a heterogeneous landscape. This aspect, closely related with the first structural axis, is fundamental to determine functional connectivity (e.g., Castellón \& Sieving 2007). Castellón \& Sieving (2006b) determined that > $25 \%$ of non-open habitat surrounding forest patches could have a significant effect on $S$. rubecula occupancy even in small $(<10 \mathrm{ha})$ fragments. A similar situation could be expected for $D$. gliroides, which is known to be able to disperse through dense scrublands (Fontúrbel et al. 2010). Considering the limited dispersal abilities of $D$. gliroides (short distances of 100 to $200 \mathrm{~m}$ ), its movement through the landscape requires closer patches and forested corridors, with some vertical structural complexity (Fontúrbel et al. 2010, Smith-Ramírez et al. 2010). Empirical evidence has shown that corridors $>25$ m wide can allow D. gliroides movement and thus persistence (Smith-Ramírez et al. 2010), which is very similar to the value estimated by Sieving et al. (2000) for S. rubecula.

Because of the positive relationship between landscape connectivity and ecological connectivity (Lindenmayer \& Fischer 2006), a diminished $D$. gliroides landscape dispersal would result in less ecological connectivity. Losing ecological connectivity would represent less inter-fragment dispersal for many native plants, and hence less gene flow. The permeability of the surrounding matrix (Ricketts 2001), ultimately determines whether this species would be capable to disperse throughout, as well as the species abundance and composition in each fragment (Ewers \& Didham 2006). A non-forested matrix will preclude $D$. gliroides dispersal, even though forest remnants are close to each other (Fontúrbel et al. 2010), confining local populations to isolated patches with no chances of gene flow or rescue effects. The amount and quality of vegetation cover would ultimately determine the willingness of forest species to enter potential corridors (Sieving et al. 2000).

Molecular evidence has shown minimum $D$. gliroides genetic differentiation levels, because of the unrestricted gene flow along its distributional range (Himes et al. 2008). Therefore, the movement restrictions that human disturbance impose could severely affect the evolutionary trajectory of this marsupial. Increasing genetic differentiation among forest remnants and causing allelic diversity loss could also change its ecoevolutionary dynamics (Kinnison \& Hairston 2007), modifying the local ecological interactions, and its role as a selection agent.

\section{Joining structure and connectivity with environ- mental policy}

The current Chilean legislation (Native Forest Law 20283, approved in 2008) considers the formulation of native forests management plans. However, the spatial configuration of the SATR is not taken into consideration under this legal framework, overlooking core habitats, key structural elements (Vergara \& Schlatter 2008), and functional connectivity. Moreover, cutting methods prescribed in the Chilean law (i.e., heavy shelter-wood and strip cutting) for forest regeneration does not consider forest-dependent species, which would decrease as a result of structural changes (Vergara \& Schlatter 2008). Consequently, the whole ecological and evolutionary dynamics of the SATR has been overlooked. On the contrary, if structure and connectivity were taken into account for the elaboration of environmental policies, a more realistic ecosystem conservation program would be achieved (Fig. 1).

Considering the current habitat loss trend (Echeverria et al. 2006), it is imperative to manage the remaining rainforest fragments appropriately, contemplating integral management plans. The absence of management of timber stocks will cause its collapse within one or two decades (Armesto et al. 2010). Consequently, forest recovery should be included in the legal framework. Future land policy should also incorporate social values and ecological factors instead of being based mostly on economic reasoning 
(Armesto et al. 2010). Our proposal may help to incorporate the ecological factors into this new policy, but socio-economic drivers of land use change should also being considered.

In the same sense as the monito del monte was proposed here as a model species, birds also were used as conservation umbrellas. In that case, Willson \& Armesto (2003) proposed five key management recommendations: (1) maintaining the extant forest patches, (2) using wooded windshields, (3) harvesting planning, (4) education, and (5) research. Although such general recommendations are extremely valuable for incorporating the ecological dimension into environmental policy, they ignore the spatial component. A spatially-explicit approach as the one we propose here might complement these recommendations and hence help developing better and more functional and sustainable policies.
Integrating these structural and connectivity components derived from studying the monito del monte would allow improving the current environmental policy in four main aspects:

(1) Promoting preservation of the extant remnants and restoring previously degraded or deforested areas, in order to increase landscape connectivity. Connecting several forest patches of different size classes would have a larger positive effect than preserving a few large and isolated remnants (Prugh et al. 2008). This scenario would allow inter-patch connectivity, benefiting $D$. gliroides and many other forest-dependent species that cannot disperse through a non-forested matrix (Castellón \& Sieving 2006b). This outcome would help maintain the ecosystem functionality, incorporating trophic complexity (Duffy et al. 2007). Additionally, preserving such animal species also would

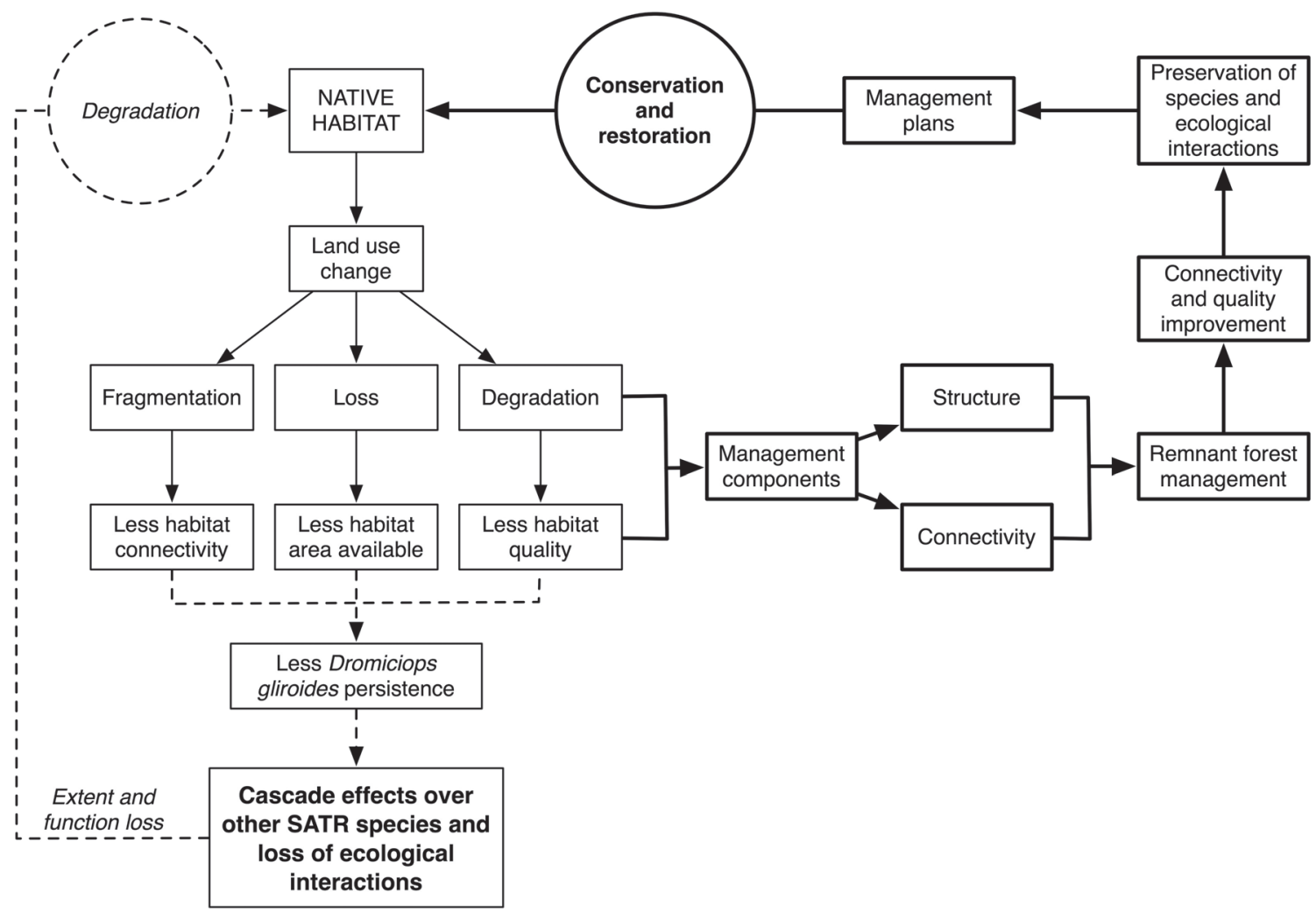

Fig. 1: Summary chart. Regular lines represent the current situation. Dashed lines represent what would happen if no actions were taken. Bold lines represent what would happen if the proposal were implemented. Circles present the final result for the native forest.

Esquema resumen. Las líneas normales muestran la situación actual. Las líneas punteadas ilustran lo que pasaría si no se toman acciones. Las líneas gruesas muestran lo que pasaría si se implementa la propuesta. Los círculos representan el resultado final para el bosque nativo. 
have a positive effect on plant species conservation, particularly specialist species that rely on mutualistic interactions (Aguilar et al. 2006).

(2) Regulating human activities over the extant forest remnants, in order to maintain the habitat quality (Jaña-Prado et al. 2006), on which also many understory bird species depend (Reid et al. 2004, Diaz et al. 2005). Those regulations should avoid the loss of key structural elements to firewood extraction or livestock grazing, aiming to maintain habitat quality and to promote natural regeneration of disturbed areas.

(3) Maintaining the ecosystem value, through services and goods (Martinez-Harms $\&$ Gajardo 2008). This could be achieved by conserving the habitat, the species, and the ecological interactions. Regulation and habitat processes are essential for the maintenance of all natural processes (Martinez-Harms \& Gajardo 2008). Particularly, conserving $D$. gliroides would allow maintaining the natural regeneration services.

(4) Generating a new environmental policy for the SATR, considering the heuristic value of the current ecological knowledge as the cornerstone of management plans.

In summary, conservation knowledge and environmental policies are closely related to each other, which is why they should not be treated separately. The case study of $D$. gliroides has illustrated this important interaction between scientific and policymaking processes. Following these simple recommendations would help conserve many other native species, which also rely on habitat quality, structure, and connectivity for its long-term persistence, as well as maintaining their eco-evolutionary dynamics (Kinnison \& Hairston 2007). With an open mind, our "environmental architects" might find the essential benefits of learning from the "ecological architects", such as the monito del monte, for the management and conservation outcomes to show significant improvement.

ACKNOWLEDGEMENTS: We thank P. Camus for inviting us to contribute to this Special Feature number. We also thank F. Barbieri, M. Franco, S. Luque, and two anonymous reviewers for their insights on our manuscript. FEF was supported by a Comisión Nacional de Investigación Científica y Tecnológica
(CONICYT) doctoral fellowship. The authors thank the Centro Nacional del Medio Ambiente CENMA, Chile, for funding the publication cost of the article.

\section{LITERATURE CITED}

AGUILAR R, L ASHWORTH, L GALETTO \& MA AIZEN (2006) Plant reproductive susceptibility to habitat fragmentation: Review and synthesis through a meta-analysis. Ecology Letters 9: 968-980.

AIZEN MA (2003) Influences of animal pollination and seed dispersal on winter flowering in a temperate mistletoe. Ecology 84: 2613-2627.

AIZEN MA \& C EZCURRA (1998) High incidence of plant-animal mutualisms in the woody flora of the temperate forest of southern South America: Biogeographical origin and present ecological significance. Ecología Austral 8: 217-236.

AIZEN MA, DP VÁSQUEZ \& C SMITH-RAMÍREZ (2002) Historial natural y conservación de los mutualismos planta-animal del bosque templado de Sudamérica austral. Revista Chilena de Historia Natural 75: 79-97.

AMICO GC \& MA AIZEN (2000) Mistletoe seed dispersal by a marsupial. Nature 408: 929-930.

AMICO GC, MA RODRÍGUEZ-CABAL \& MA AIZEN (2009) The potential key seed-dispersing role of the arboreal marsupial Dromiciops gliroides. Acta Oecologica 35: 8-13.

AMICO GC, MA RODRÍGUEZ-CABAL \& MA AIZEN (2011) Geographic variation in fruit colour is associated with contrasting seed disperser assemblages in a south-Andean mistletoe. Ecography 34: 318-326.

ARMESTO JJ, D MANUSCHEVICH, A MORA, C SMITH-RAMIREZ, R ROZZI et al. (2010) From the Holocene to the Anthropocene: A historical framework for land cover change in southwestern South America in the past 15,000 years. Land Use Policy 27: 148-160.

BENTLEY JM (2008) Role of movement, interremnant dispersal and edge effects in determining sensitivity to habitat fragmentation in two forestdependent rodents. Austral Ecology 33: 184-196.

BEYER GL, RL GOLDINGAY \& DJ SHARPE (2008) The characteristics of squirrel glider (Petaurus norfolcensis) den trees in subtropical Australia. Australian Journal of Zoology 56: 13-21.

BOZINOVIC F, G RUIZ \& M ROSENMANN (2004) Energetics and torpor of a South American "living fossil", the microbiotheriid Dromiciops gliroides. Journal of Comparative Physiology 174: 293-297.

BRO-JØRGENSEN J (2008) Dense habitats selecting for small body size: A comparative study on bovids. Oikos 117: 729-737.

BUTCHART SHM, M WALPOLE, B COLLEN, A VAN STRIEN, JPW SCHARLEMANN et al. (2010) Global biodiversity: Indicators of recent declines. Science 328: 1164-1168.

CARMONA MR, JC ARAVENA, MA BUSTAMANTESANCHEZ, JL CELIS-DIEZ, A CHARRIER et al. (2010) Senda Darwin biological station: Longterm ecological research at the interface between science and society. Revista Chilena de Historia Natural 83: 113-142.

CASTELLÓN TD \& KE SIEVING (2006a) An experimental test of matrix permeability and 
corridor use by an endemic understory bird. Conservation Biology 20: 135-145.

CASTELLON TD \& KE SIEVING (2006b) Landscape history, fragmentation, and patch occupancy: Model for a forest bird with limited dispersal. Ecological Applications 16: 2223-2234.

CASTELLÓN TD \& KE SIEVING (2007) Patch network criteria for dispersal-limited endemic birds of South American temperate rain forest. Ecological Applications 17: 2152-2163.

CELIS-DIEZ JL (2010) Historia natural y demografía del marsupial arbóreo Dromiciops gliroides en bosques nativos primarios y degradados del norte de la Isla Grande de Chiloé. PhD Thesis, Faculty of Sciences, Universidad de Chile, Santiago.

CHAPIN III FS, ES ZAVALETA, VT EVINER, RL NAYLOR, PM VITOUSEK et al. (2000) Consequences of changing biodiversity. Nature 405: 234-242.

COCKLE KL, K MARTIN \& MC DREVER (2010) Supply of tree-holes limits nest density of cavitynesting birds in primary and logged subtropical Atlantic forest. Biological Conservation 143: 2851-2857.

CORNELIUS $\mathrm{C}, \mathrm{K}$ COCKLE, $\mathrm{N}$ POLITI, I BERKUNSKY, L SANDOVAL et al. (2008) Cavity-nesting birds in Neotropical forests: Cavities as a potentially limiting resource. Ornitologia Neotropical 19: 253-268.

DÍAZ IA, JJ ARMESTO, S REID, KE SIEVING \& MF WILLSON (2005) Linking forest structure and composition: Avian diversity in successional forests of Chiloé Island, Chile. Biological Conservation 123: 91-101.

DIAZ IA, JJ ARMESTO \& MF WILLSON (2006) Mating success of the endemic Des Murs' Wiretail (Sylviorthorhynchus desmursii, Furnariidae) in fragmented Chilean rainforests. Austral Ecology 31: $13-21$.

DUFFY JE, BJ CARDINALE, KE FRANCE, PB MCINTYRE, E THÉBAULT et al. (2007) The functional role of biodiversity in ecosystems: Incorporating trophic complexity. Ecology Letters 10: 522-538.

ECHEVERRÍA C, D COOMES, J SALAS, JM REYBENAYAS, A LARA et al. (2006) Rapid deforestation and fragmentation of Chilean temperate forest. Biological Conservation 130: 481-494.

ECHEVERRÍA C, A NEWTON, A LARA, JM REYBENAYAS \& D COOMES (2007) Impact of forest fragmentation on species composition and forest structure in the temperate landscape of southern Chile. Global Ecology and Biogeography 16: 426-439.

EWERS RM \& RK DIDHAM (2006) Confounding factors in the detection of species responses to habitat fragmentation. Biological Reviews 81: 117-142.

FAHRIG L (1997) Relative effects of habitat loss and fragmentation on population extinction. Journal of Wildlife Management 61: 603-610.

FAHRIG L (2003) Effects of habitat fragmentation on biodiversity. Annual Review of Ecology \& Systematics 34: 487-515.

FISCHER J, DB LINDENMAYER \& R MONTAGUEDRAKE (2008) The role of landscape texture in conservation biogeography: A case study on birds in south-eastern Australia. Diversity and Distributions 14: 38-46.
FONTÚRBEL FE (2010) A methodological approach to assess the small mammal community diversity in the temperate rainforest of Patagonia. Mammalian Biology 75: 294-301.

FONTURBEL FE \& JE JIMENEZ (2009) Underestimation of abundances of the monito del monte (Dromiciops gliroides) due to a sampling artifact. Journal of Mammalogy 90: 1357-1362.

FONTÚRBEL FE, EA SILVA-RODRÍGUEZ, NH CARDENAS \& JE JIMENEZ (2010) Spatial ecology of monito del monte (Dromiciops gliroides) in a fragmented landscape of southern Chile. Mammalian Biology 75: 1-9.

FRANCO LM (2009) Agrupamiento durante el sopor: Mecanismos proximales y consecuencias ecológicas en el marsupial ancestral monito del monte (Dromiciops gliroides, Marsupialia: Microbiotheria). PhD Thesis, Faculty of Sciences, Universidad Austral, Valdivia, Chile.

GALLARDO-SANTIS A, JA SIMONETTI \& RA VÁSQUEZ (2005) Influence of tree diameter on climbing ability of small mammals. Journal of Mammalogy 86: 969-973.

GARCÍA D, MA RODRÍGUEZ-CABAL \& G AMICO (2009) Seed dispersal by a frugivorous marsupial shapes the spatial scale of a mistletoe population. Journal of Ecology 97: 217-229.

GIBBONS P, DB LINDENMAYER, SC BARRY \& MT TANTON (2002) Hollow selection by vertebrate fauna in forests of southeastern Australia and implications for forest management. Biological Conservation 103: 1-12.

HERSHKOVITZ P (1999) Dromiciops gliroides Thomas, 1894, last of the Microbiotheria (Marsupialia), with a review of the family Microbiotheriidae. Fieldiana Zoology 93: 1-60.

HIMES CMT, MH GALLARDO \& GJ KENAGY (2008) Historical biogeography and post-glacial recolonization of South American temperate rain forest by the relictual marsupial Dromiciops gliroides. Journal of Biogeography 35: 1415-1424.

JAÑA-PRADO R, JL CELIS-DIEZ, AG GUTIÉRREZ, C CORNELIUS \& JJ ARMESTO (2006) Diversidad en bosques fragmentados de Chiloé: ¿Son todos los fragmentos iguales? In: Grez AA, JA Simonetti \& RO Bustamante (eds) Biodiversidad en ambientes fragmentados de Chile: Patrones y procesos a diferentes escalas: 159-189. Editorial Universitaria, Santiago, Chile.

JIMÉNEZ JE \& R RAGEOT (1979) Notas sobre la biología del monito del monte (Dromiciops australis Philippi 1893). Anales del Museo de Historia Natural de Valparaíso (Chile) 12: 83-88.

KELT DA \& DR MARTÍNEZ (1989) Notes on distribution and ecology of two marsupials endemic to the Valdivian forests of southern South America. Journal of Mammalogy 70: 220224.

KINNISON MT \& NG HAIRSTON (2007) Ecoevolutionary conservation biology: Contemporary evolution and the dynamics of persistence. Functional Ecology 21: 444-454.

LINDENMAYER DB (1999) Future directions for biodiversity conservation in managed forests: Indicator species, impact studies and monitoring programs. Forest Ecology and Management 115: 277-287.

LINDENMAYER DB, RB CUNNINGHAM, ML POPE \& 
CF DONNELY (1999) The response of arboreal marsupials to landscape context: A large-scale fragmentation study. Ecological Applications 9: 594-611.

LINDENMAYER DB \& J FISCHER (2006) Habitat fragmentation and landscape change. Island Press, Washington, EEUU.

LINDENMAYER DB, AD MANNING, PL SMITH, HP POSSINGHAM, J FISCHER et al. (2002) The focal-species approach and landscape restoration: A critique. Conservation Biology 16: 338-345.

LOBOS G, A CHARRIER, G CARRASCO \& RE PALMA (2006) Presence of Dromiciops gliroides (Microbiotheria: Microbiotheriidae) in the deciduous forests of central Chile. Mammalian Biology 70: 376-380.

MARGALIDA A, JA DONAZAR, M CARRETE \& JA SANCHEZ-ZAPATA (2010) Sanitary versus environmental policies: Fitting together two pieces of the puzzle of European vulture conservation. Journal of Applied Ecology 47: 931935.

MARSHALL LG (1978) Dromiciops australis. Mammalian Species 99: 1-5.

MARTINEZ-HARMS MJ \& R GAJARDO (2008) Ecosystem vague in the western Patagonia protected areas. Journal for Nature Conservation 16: 72-87.

MITTERMEIER RA, PR GIL, M HOFFMAN, J PILGRIM, T BROOKS et al. (eds) (2005) Hotspots revisited: Earth's biologically richest and most threatened terrestrial ecoregions. CEMEX, Monterrey, Mexico.

MYERS N, RA MITTERMEIER, CG MITTERMEIER, GAB DA FONSECA \& J KENT (2000) Biodiversity hotspots for conservation priorities. Nature 403: 853-858.

PATTERSON BD, PL MESERVE \& BK LANG (1990) Quantitative habitat associations of small mammals along an elevational transect in temperate rainforest of Chile. Journal of Mammalogy 71: 620-633.

PRUGH LR, KE HODGES, ARE SINCLAIR \& JS BRASHARES (2008) Effect of habitat area and isolation on fragmented animal populations. Proceedings of the National Academy of Sciences USA 105: 20770-20775.

QUIJANO SA (2008) Uso y selección del hábitat del monito del monte Dromiciops gliroides Thomas, 1894, en el Bosque Experimental San Martín, Valdivia-Chile. PhD Thesis, Faculty of Sciences, Universidad Austral, Valdivia.

REID S, IA DÍAZ, JJ ARMESTO \& MF WILLSON (2004) Importance of native bamboo for understory birds in Chilean temperate forests. Auk 121: 515-525.

RICKETTS TH (2001) The matrix matters: Effective isolation in fragmented landscapes. American Naturalist 158: 87-99.

RIES L \& TD SISK (2004) A predictive model of edge effects. Ecology 85: 2917-2926.

RODRÍGUEZ-CABAL MA (2008) Habitat assessment for a threatened marsupial in temperate rainforest of Patagonia. MSc. Thesis, Wildlife Ecology and Conservation Department, University of Florida, Gainesville FL.

RODRÍGUEZ-CABAL MA, MA AIZEN \& AJ NOVARO (2007) Habitat fragmentation disrupts a plantdisperser mutualism in the temperate forest of South America. Biological Conservation 139: 195-202.

SALA OE, FS CHAPIN, JJ ARMESTO, E BERLOW, J BLOOMFIELD et al. (2000) Biodiversity - Global biodiversity scenarios for the year 2100 . Science 287: 1770-1774.

SIEVING KE, MF WILLSON \& TL DE SANTO (2000) Defining corridor functions for endemic birds in fragmented south-temperate rainforest. Conservation Biology 14: 1120-1132.

SIMONETTI JA, AA GREZ, JL CELIS-DIEZ \& RO BUSTAMANTE (2007) Herbivory and seedling performance in a fragmented temperate forest of Chile. Acta Oecologica-International Journal of Ecology 32: 312-318

SMITH-RAMÍREZ C, JL CELIS-DIEZ, E VON JENSTCHYK, JE JIMÉNEZ \& JJ ARMESTO (2010) Habitat use of remnant forest habitats by threatened arboreal marsupial Dromiciops gliroides (Microbiotheria) in a rural landscape of southern Chile. Wildlife Research 37: 249-254.

VALDIVIA CE \& JA SIMONETTI (2007) Decreased frugivory and seed germination rate do not reduce seedling recruitment rates of Aristotelia chilensis in a fragmented forest. Biodiversity and Conservation 16: 1593-1602.

VALDIVIA CE, JA SIMONETTI \& CA HENRÍQUEZ (2006) Depressed pollination of Lapageria rosea Ruiz et pav. (Philesiaceae) in the fragmented temperate rainforest of Southern South America. Biodiversity and Conservation 15: 1845-1856.

VÁSQUEZ DP (2005) Reconsiderando el nicho hutchinsoniano. Ecología Austral 15: 149-158.

VÁSQUEZ RA \& JA SIMONETTI (1999) Life history traits and sensitivity to landscape change: The case of birds and mammals of mediterranean Chile. Revista Chilena de Historia Natural 72: 517-525.

VERGARA PM \& JJ ARMESTO (2009) Responses of Chilean forest birds to anthropogenic habitat fragmentation across spatial scales. Landscape Ecology 24: 25-38.

VERGARA PM \& RP SCHLATTER (2008) Conservation of birds in evergreen Chilean forests: The effect of partial cutting systems. Wildlife Research 35 : 134-139.

WIENS JA (1997) Metapopulation dynamics and landscape ecology. In: Hanski I \& M Gilpin (eds) Metapopulation biology: Ecology, genetics, and evolution: 43-62. Academic Press, Burlington, EEUU.

WILLSON MF \& JJ ARMESTO (2003) Efectos de la fragmentación de bosques para las aves de los bosques australes chilenos. Ambiente y Desarrollo 19: 54-59. 
